\title{
Formulation of mouth rinse from the essential oils of lime (Citrus aurantifolia) and its inhibitory efficacy on the growth of Streptococcus mutans - in vitro
}

\author{
Sri Mulyanti ${ }^{1}$, Dewi Sodja Laela ${ }^{1}$, Euis Julaeha ${ }^{2}$, Anne Agustina Suwargiani ${ }^{3}$, \\ Dudi Aripin ${ }^{4 *}$ \\ ${ }^{1}$ Department of Dental Health, Dental Nursing Study Program, Bandung Polytechnic of Health, \\ Indonesia \\ 2Department of Chemistry, Faculty of Mathematics and Natural Sciences Universitas Padjadjaran, \\ Indonesia \\ ${ }^{3}$ Department of Dental Public Health, Faculty of Dentistry Universitas Padjadjaran, Indonesia \\ ${ }^{4}$ Department of Conservative Dentistry, Faculty of Dentistry Universitas Padjadjaran, Indonesia
}

\begin{abstract}
Introduction: Essentials oil of lime (Citrus aurantifolia) peel has high activity in inhibiting the growth of Streptococcus mutans bacteria. The objective of this research was to determine the formulation of mouth rinse from the essential oils of lime (C. aurantifolia) with the highest inhibitory and on the growth of $S$. mutans. Methods: This research was an experimental in-vitro study. The sample used was the lime ( $C$. aurantifolia) peel waste peel using hydrodistillation technique; testing of the essential oil quality was performed using $100^{\circ} \mathrm{C}$ distilled water for 3 hours; organoleptic test and physical mouth rinse formula test was also conducted. Mouth rinse formulations were made from the essential oils in the concentrations of $1,2,4,8,10$, and $20 \%$. Mouth rinse activity was tested with optical density. Minimum inhibitory concentration was determined with microdilution. Results: Essential oil mouth rinse formulation showed antibacterial activity at the concentrations of 2, 4, 8, 10, and 20\% (formulations I-IV); the recommended mouth rinse concentration was $4 \%$ (formulation III) due to its highest antibacterial. Formulation IV showed the highest minimum inhibitory concentration value of $5.2 \mathrm{mg} / \mathrm{mL}(0.52 \%)$ and the safe minimum bactericidal concentration of $0.4 \mathrm{mg} / \mathrm{mL}$ (1.04). Conclusion: Mouth rinse formulation from essential oils of lime ( $C$. aurantifolia) peel begins to show inhibition of the growth of $S$. mutans bacteria at the concentration of $2 \%$ essential oils (formulation II), with inhibition against the growth of $S$. mutans is 7.08. The formula shows a minimum inhibitory concentration (MIC) value and a minimum bactericidal concentration $(\mathrm{MBC})$ of $5.2 \mathrm{mg} / \mathrm{mL}(0.52 \%)$ and $10.4 \mathrm{mg} / \mathrm{mL}(1.04)$, respectively.
\end{abstract}

Keywords: Lime peel, Streptococcus mutans, essential oils, Citrus aurantifolia, mouth rinse.

p-ISSN: 1979-0201; e-ISSN: 2549-6212; Available from: http://jurnal.unpad.ac.id/pjd/article/view/25486

DOI: 10.24198/pid.vol32no1.25486

Submission: Jan 03, 2020; Accepted: Mar 11, 2020; Published online: Mar 31, 2020

"Corresponding author: Dudi Aripin, Department of Conservative Dentistry, Faculty of Dentistry Universitas Padjadjaran, Indonesia. Jalan Sekeloa Selatan I, Bandung, West Java, Indonesia, 40132. Phone: +628112342972; Email: dudi.aripin@fkg. unpad.ac.id 


\section{INTRODUCTION}

Throughout the world, dental caries is a major oral health problem in children, adults ${ }^{1,2}$, pregnant women $^{3,4}$, and elderly. ${ }^{5,6}$ The incidence of dental caries in developing countries, especially in Indonesia, is still quite high. As many as 45.3 Indonesian people have decayed teeth/cavities/ toothache in almost all age groups. ${ }^{7}$

Dental caries is a multifactorial ${ }^{1,2}$, chronic, preventable, and localised disease as a result of interactions between host, bacteria, food, and time, which causes cavitation of inorganic components in the enamel and dentin. ${ }^{8}$ Caries is an infectious disease caused by the presence of oral bacteria, primarily initiated by Streptococcus mutans $^{1,8}$, and also as the results of Lactobacillus development. ${ }^{8}$ Tooth decay due to untreated caries can cause difficulties in eating and sleeping, thus affecting the growth of children and is a significant cause of absence from school and work. ${ }^{2}$

Evaluation of the number of Streptococcus mutans in the plaque and saliva can help the diagnosis of caries activity. In conjunction with this concept, control and prevention of caries have been sought by reducing the number of bacteria. ${ }^{2}$ Oral diseases, mainly dental caries and plaque formation, occur in almost everyone. With the high prevalence of dental caries in Indonesia and the discovery of active antibacterial compounds against dental caries bacteria, it is fundamental to conduct studies on the search for a drug that can suppress the development of dental caries bacteria from Indonesian plants.

The utilisation of medicinal plants in the field of dentistry is still rare. Research that has been conducted are concerning pineapple, starfruit, and basil methanol extract on caries inhibition, ${ }^{9}$ and also methanol extract of ant-plant (Myrmecodia pendens Merr. \& Perry) tubers ${ }^{10}$ and rosella petals ${ }^{11}$ against Streptococcus mutans. Research concerning the activity of orange peel oil is still rarely conducted.

Lime is able to inhibit plaque formation by inhibiting pellicle formation, growth of germ colonies, increasing salivary velocity, and decreasing salivary viscosity. ${ }^{14}$ Increasing salivary flow speed and decreasing salivary viscosity are able to inhibit the plaque formation. ${ }^{14}$ The results of previous studies indicated that orange peels essential oil are very effective and potential in inhibiting the growth of $S$. mutans, which expected to replace synthetic antibacterial medications because it is relatively safe due to its natural origin. ${ }^{14}$

We have conducted preliminary study regarding the activity test of the five types of orange peel oil on the growth of S. mutans, which showed that all samples could inhibit the growth of the bacteria with inhibitory potentials as follows:

(i) essential oils of lime (C. aurantifolia) 10.80 $\mathrm{mm}$; (ii) Siamese orange (C. nobilis) $10.10 \mathrm{~mm}$; (iii) Berastagi orange (C. sinensis) $10.10 \mathrm{~mm}$; (iv) Lemon (C. limon) $10.50 \mathrm{~mm}$; and (v) Kaffir lime (C. hystrix) $10.40 \mathrm{~mm} .{ }^{12}$ Lime (C. aurantifolia) is known to have the highest activity in inhibiting the growth of S. mutans. The essential oil from orange peels is suggested to have antimicrobial activity. ${ }^{12,13}$

With the discovery of lime peel essential oils that are effective and potential in inhibiting the growth of $S$. mutans bacteria, hope arises that these essential oils can be used as an antibacterial agent for oral diseases. Thus it is expected to replace synthetic antibacterials. After all, it is relatively safe because it is made from natural ingredients; thus, dependence on synthetic drugs can be more suppressed. However, studies of the lime peel essential oil formula on the growth of $S$. mutans have not been reported.

The current research was an advance study that conducted to produce a mouth rinse solution from the essential oils of lime and to analyse the effective concentration of the inhibitory potential against Streptococcus mutans. The objectives of the present study was to determine the formulation of mouth rinse from the essential oils of lime ( $C$. aurantifolia) with the highest inhibitory and on the growth of S. mutans.

\section{METHODS}

The type of this research was experimental in vitro. The sample used was the lime ( $C$. aurantifolia) peel waste obtained from Ciawigebang Village of the Ciawi District in Kuningan Regency. The research consisted of four stages described as follows:

\section{Preparation of essential oils from C. aurantifolia peel by hydrodistillation technique}

The preparation of essential oils was taken from $C$. aurantifolia peel using hydrodistillation technique; 
testing of the quality of the essential oils was performed using $100^{\circ} \mathrm{C}$ distilled water for 3 hours.

\section{Testing the quality of essential oils}

The testing of essential oil's quality consisted of four tests included determination of the specific gravity using a pycnometer; determination of the refractive index using a refractometer; determination of the solubility value in alcohol; and determination of the acid value with the acid-base titration method. Uji organoleptisnya dilakukan untuk menilai homogenitas, warna, bau, dan rasa.

\section{Formulation of the mouth rinse}

The mouth rinse formulation was made in concentrations of $1,2,4,8,10$, and $20 \%$ to found the optimum activity against S. mutans. Mouth rinse activity was tested with optical density.

\section{Activity test of the mouth rinse}

Minimum inhibitory concentration was determined with microdilution; organoleptic test and physical mouth rinse formula test was also conducted.

\section{RESULTS}

The results of this study are presented in the order of which they were carried out as follows:

\section{Results of determination of C. aurantifolia essential oil quality}

The preparation of $5.93 \mathrm{~kg}$ of $C$. aurantifolia peel produced $36.78 \mathrm{~g}$ of essential oil with the yields of $0.62 \%$. The quality of $C$. aurantifolia essential oil in this study was clear and had a uniquely fresh aroma. The results of determination of $C$. aurantifolia essential oil quality are listed in Table 1.

Table 1. Results of determination of $C$. aurantifolia essential oil quality

\begin{tabular}{lcc}
\hline \multicolumn{1}{c}{ Quality type } & Determination results & Literature standards* \\
\hline Density $\left(25^{\circ} \mathrm{C}\right)$ & $0.834 \mathrm{~g} / \mathrm{mL}$ & $0.862-0.868 \mathrm{~g} / \mathrm{mL}$ \\
Refractive index $\left(25^{\circ} \mathrm{C}\right)$ & 1.5536 & $1.4750-1.4770$ \\
Acid value & $1.37 \%$ & $0.5-1.5 \%$ \\
Solubility in alcohol & Soluble in $90 \%$ ethanol & Soluble in $90 \%$ ethanol \\
& volume $4.5 \mathrm{~mL}$ & volume $4 \mathrm{~mL}$ \\
\hline
\end{tabular}

The results presented in Table 1 show that the values of essential oil quality parameters were close to the standards from the literature. The standards were taken from the literature standards because both national and international standards of lime essential oils have not enforced yet. The quality of essential oils is highly influenced by the geographical location of the plantation growth, the nutrients and enzymes present in the plants, and other related factors.

\section{Formulation of the mouth rinse}

Mouth rinse formulations were made in six variations to determine the most optimal formula in inhibiting the growth of oral disease microbial agent, namely S. mutans. Concentration variations were made in $1,2,4,8,10$, and $20 \%$; while other additives are made permanent, to determine the optimum concentration of the lime essential oil active substances, as listed in Table 2 and Figure 2.

Table 2. Variation of lime essential oil mouth rinse formula with concentration variations

\begin{tabular}{lcccccc}
\hline \multirow{2}{*}{ Materials } & \multicolumn{7}{c}{ Formula } \\
\cline { 2 - 7 } & I & II & III & IV & V & VI \\
\hline Essential oil (\%) & 1 & 2 & 4 & 8 & 10 & 20 \\
Tween 80 (\%) & 10 & 10 & 10 & 10 & 10 & 10 \\
Pepermint (\%) & 1 & 1 & 1 & 1 & 1 & 1 \\
Na-Benzoat (\%) & 0.4 & 0.4 & 0.4 & 0.4 & 0.4 & 0.4 \\
Na-Saccharine (\%) & 6 & 6 & 6 & 6 & 6 & 6 \\
Stain (\%) & 0.2 & 0.2 & 0.2 & 0.2 & 0.2 & 0.2 \\
100 $\mathrm{mL}$ aquadest addition & 100 & 100 & 100 & 100 & 100 & 100 \\
\hline
\end{tabular}




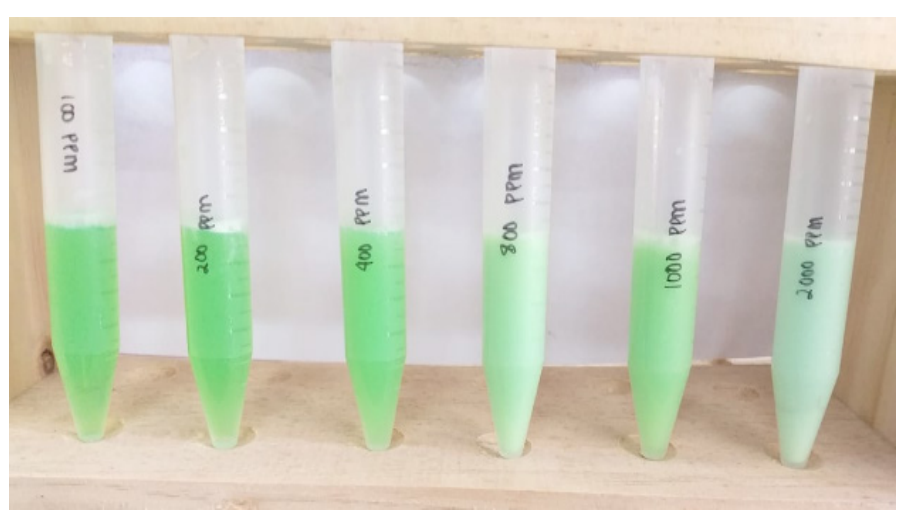

Figure 2. Visual form of mouth rinse solutions with lime essential oil active ingredients in various concentrations

Afterwards, formula with a concentration of $2 \%$ essential oil, making glycerin with concentration variation and tween as an emulsifier was carried out, as described in Table 3 and Figure 2.

The formula with $2 \%$ essential oils concentration (formula II) was a formula with a minimum concentration that able to inhibit the growth of S. Mutans. The variations in the concentration of Tween 80 emulsifiers and glycerin sweeteners were tested and measured to determine the best formula.

However, the visual results were not good enough because the appearance of the solutions was murky (IIA-IIF).

Table 3. Mouth rinse formula with $2 \%$ lime essential oil concentration and variations in concentrations of Tween and glycerin emulsifiers

\begin{tabular}{lcccccc}
\hline \multirow{2}{*}{ Materials } & \multicolumn{7}{c}{ Formula } \\
\cline { 2 - 7 } & IIA & IIB & IIC & IID & IIE & IIF \\
\hline Essential oil (\%) & 2 & 2 & 2 & 2 & 2 & 2 \\
Tween 80 (\%) & 0.5 & 1 & 1.5 & 2 & 2.5 & 3 \\
Glycerin (\%) & 4.5 & 4 & 3.5 & 3 & 2.5 & 2 \\
Pepermint (\%) & 0.05 & 0.05 & 0.05 & 0.05 & 0.05 & 0.05 \\
Na-Benzoat (\%) & 0.02 & 0.02 & 0.02 & 0.02 & 0.02 & 0.02 \\
Na-Saccharine (\%) & 0.06 & 0.06 & 0.06 & 0.06 & 0.06 & 0.06 \\
Stain (\%) & 0.01 & 0.01 & 0.01 & 0.01 & 0.01 & 0.01 \\
100 mL aquadest addition & 100 & 100 & 100 & 100 & 100 & 100 \\
\hline
\end{tabular}

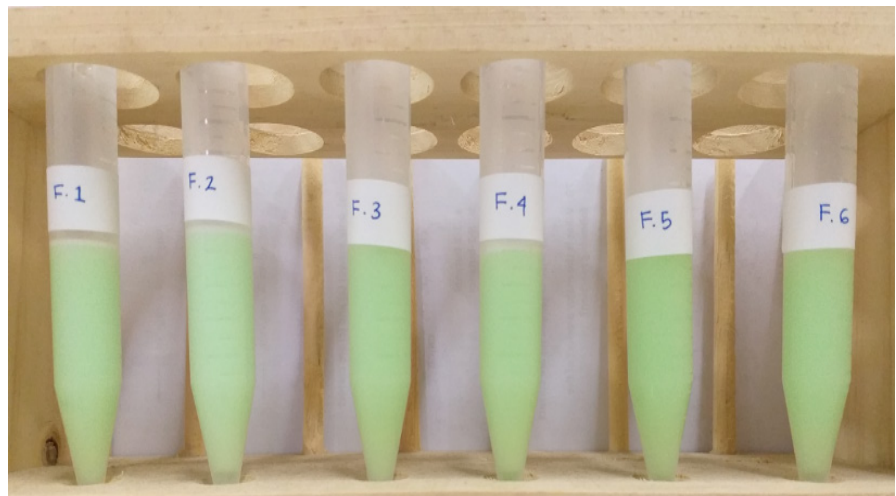

Figure 2. Visual form of mouth rinse solutions with $2 \%$ lime essential oil concentration and variations of Tween and glycerin emulsifiers

\section{Results of organoleptic test}

Table 4 show the results of organoleptic test of formula I-VI and formula VII-XII. Specifically, Table
4 presents the results of organoleptic test of formula I-VI, namely formulas with variations in the concentration of essential oils; 
Table 4. Results of organoleptic observation mouth rinse with formula I-VI

\begin{tabular}{lccccc}
\hline No & Mouth rinse formula & Homogeneity / Clarity & Aroma & Colour & Flavour \\
\hline 1. & I & Homogeneous, clear & Mint & Clear green & + Sweet \\
2. & II & Homogeneous, clear & Mint & Clear green & + Sweet \\
3. & III & Homogeneous, clear & Fresh, typical of essential oils & Clear green & + Sweet \\
4. & IV & Homogeneous, turbid & Fresh, typical of essential oils & Murky green & + Sweet \\
5. & V & Homogeneous, turbid & Fresh, typical of essential oils & Murky green & + Sweet \\
6. & VI & Homogeneous, turbid & Fresh, typical of essential oils & Murky green & + Sweet \\
\hline
\end{tabular}

Results of physical properties test

Characterisation of the physical properties included the $\mathrm{pH}$ value, density, and viscosity, with the results shown in Table 5

Table 5. Observation results of the physical properties of mouthwash of formula I-VI

\begin{tabular}{lcccc}
\hline No & Mouth rinse formula & $\mathrm{pH}$ & Density $\left(\mathrm{g} / \mathrm{cm}^{3}\right)$ & Viscosity $(\mathrm{cSt})$ \\
\hline 1. & $\mathrm{I}$ & 6.20 & 1.006 & 1.530 \\
2. & $\mathrm{II}$ & 6.11 & 1.005 & 1.451 \\
3. & $\mathrm{III}$ & 6.09 & 1.002 & 1.495 \\
4. & $\mathrm{IV}$ & 6.04 & 0.997 & 1.738 \\
5. & $\mathrm{~V}$ & 6.03 & 0.997 & 2.162 \\
6. & $\mathrm{VI}$ & 5.77 & 0.986 & 2.934 \\
\hline
\end{tabular}

Results of mouth rinse antibacterial activity test

Antibacterial activity of the mouth rinse against S. mutans was tested to find the optimum concentration of essential oils used, with the results listed in Table 6 and Figure 3. The positive control used was chlorhexidine, with negative control in the form of distilled water.

Table 6. Determination of the Minimum Inhibition Concentration against S. mutans ATCC 25175 (Formula II)

\begin{tabular}{lccccccccccccccc}
\hline \multirow{2}{*}{ Well } & \multicolumn{1}{c}{ Concentration (ppm) } \\
\cline { 2 - 10 } & 166800 & $\mathbf{8 3 4 0 0}$ & $\mathbf{4 1 7 0 0}$ & $\mathbf{2 0 8 5 0}$ & $\mathbf{1 0 4 2 5}$ & $\mathbf{5 2 1 2 . 5}$ & $\mathbf{2 6 0 6 . 2 5}$ & 1303.13 & 652 & 326 & 163 & $\mathbf{8 1}$ \\
\hline Media + Sample & 1.477 & 0.357 & 0.140 & 0.072 & 0.062 & 0.058 & 0.057 & 0.057 & 0.057 & 0.057 & 0.058 & 0.055 \\
Media + Emulsifier & 0.063 & 0.061 & 0.057 & 0.056 & 0.056 & 0.056 & 0.056 & 0.056 & 0.057 & 0.056 & 0.057 & 0.057 \\
Media + Sample + Bacteria & 1.341 & 0.407 & 0.120 & 0.075 & 0.061 & 0.087 & 0.428 & 0.550 & 0.621 & 0.574 & 0.622 & 0.552 \\
Media + Emulsifier + Bacteria & 0.494 & 0.566 & 0.647 & 0.684 & 0.681 & 0.690 & 0.667 & 0.645 & 0.591 & 0.594 & 0.603 & 0.576 \\
\% Cell death & 131.453 & 91.735 & 103.341 & 99.515 & 100.072 & 95.395 & 39.366 & 16.249 & -5.374 & 3.738 & -3.188 & 4.533 \\
\hline
\end{tabular}

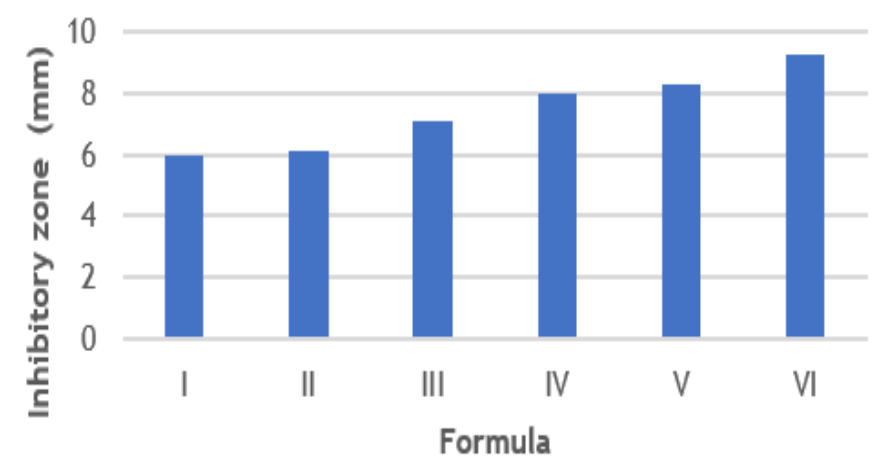

Figure 3. Graph of S. mutans growth inhibition by mouthwash of formula I-VI

The measurement results showed that the formulation of essential oils has the activity of inhibiting the growth of $S$. mutans with a minimum concentration of $5,212.5 \mathrm{ppm}$, equals to 5.2125 $\mathrm{mg} / \mathrm{ml}(0.52 \%)$ Table 7.

Based on observations, essential oils of lime 
Table 8. Determination of the Minimum Bactericidal Concentration against S. mutans ATCC 25175 (Formula II)

\begin{tabular}{cc|c|c}
\hline \multirow{2}{*}{ Sample } & \multirow{2}{*}{ Concentration (ppm) } & \multicolumn{2}{|c}{ Results } \\
\cline { 2 - 3 } & 166,800 & Repetition 1 & Repetition 2 \\
\hline \multirow{2}{*}{ Essential oils formula } & 83,400 & Negative & Negative \\
& 41,700 & Negative & Negative \\
& 20,850 & Negative & Negative \\
& 10,425 & Negative & Negative \\
& $5,212.5$ & Negative & Negative \\
\hline
\end{tabular}

has bactericidal activity against Streptococcus mutans at the concentration of $10.425 \mathrm{ppm}$ or $10.425 \mathrm{mg} / \mathrm{ml}$. The minimum inhibitory concentration (MIC) of formula II was $5.2 \mathrm{mg}$
/ $\mathrm{mL}(0.52 \%)$, and the minimum bactericidal concentration $(\mathrm{MBC})$ was $10.4 \mathrm{mg} / \mathrm{mL}(1.04 \%)$ Table 8.

The results of the three tests (organoleptic,

Table 8. Antibacterial activity of different mouthwash formulas against S. mutans

\begin{tabular}{|c|c|c|c|c|c|c|}
\hline \multirow{2}{*}{ No } & \multirow{2}{*}{ Mouth rinse formula } & \multirow{2}{*}{$\begin{array}{l}\text { Essential oil concentration } \\
\qquad(\%)\end{array}$} & \multicolumn{2}{|c|}{ Inhibitory diameter $(\mathrm{d} / \mathrm{mm})$} & \multirow{2}{*}{$\begin{array}{l}\text { Diameter average } \\
(\mathrm{mm})\end{array}$} & \multirow{2}{*}{ Notes } \\
\hline & & & 1 & 2 & & \\
\hline 1. & 1 & 1 & 6.00 & 6.00 & 6.00 & Not active \\
\hline 2. & II & 2 & 6.05 & 6.25 & 6.15 & Active \\
\hline 3. & III & 4 & 7.10 & 7.05 & 7.08 & Active \\
\hline 4. & IV & 8 & 7.90 & 8.10 & 8.00 & Active \\
\hline 5. & V & 10 & 8.10 & 8.50 & 8.30 & Active \\
\hline 6. & VI & 20 & 9.05 & 9.45 & 9.25 & Active \\
\hline 7. & Control + & & 10.05 & 10.15 & 10.10 & Susceptible \\
\hline 8. & Control - & & 6.00 & 6.00 & 6.00 & Not active \\
\hline
\end{tabular}

Control +: chlorhexidine; Control -: aquadest

physical properties, and inhibitory properties) showed that the concentration of $2 \%$ essential oils (Formula II) showed the best results which were equal to negative control values.

\section{DISCUSSION}

The preparation of $5.93 \mathrm{~kg}$ of $C$. aurantifolia peel produced $36.78 \mathrm{~g}$ of essential oil with the yields of $0.62 \%$. This result was included in the criteria of quite good yields according to Preedy ${ }^{15}$ which stated that the lime peel essential oils yields range from 0.3 to $0.9 \%$.

Physical parameters presented in Table 1 show that the values of essential oil quality parameters were close to the standards from the literature. The standards were taken from the literature standards because both national and international standards of lime essential oils have not enforced yet. The essential oils quality can be influenced by various factors including methods and ingredients used, apart from visual colours and aromas. It is also affected by more factors including the geographical location of the plant, plant varieties, ways of planting, methods of preparation, and even the conditions of different plantings.

The increase in the essential oils refractive index value can be caused by two things, namely because of the water content presence, or because of the terpene class oxidation, where oxidised terpenoids have higher molecular weights and densities than non-oxidised terpenoid groups. According to Dugo and Mondello16, the refractive index value is also influenced by the presence of water in the composition of the essential oils. The more the water content, the smaller the refractive index value, because of the nature of the water which easily refracts the incoming light.

Solubility in alcohol is a comparison value of the amount of the essential oils that dissolve completely with an alcohol solvent. Each essential oil has a specific alcohol solubility value. Thus this property can be used to determine the purity of the 
essential oils. According to Preedy ${ }^{15}$, essential oils with high concentrations of terpenoid compounds are more difficult to dissolve in water but more easily dissolve in ethanol. The results obtained in the current research indicate that the results of the quality tests (refractive index, alcohol solubility, acid value and density of essential oils were close to the literature ${ }^{15}$ (Table 1 ).

The ingredients added to the formula, each has the following functions: Lime essential oils is an ingredient that contains active substances from a group of secondary metabolites of monoterpenes and sesquiterpenes as antibacterial, with the main components of $\mathrm{D}$-limonene, B-pinene, terpinene-4 -ol and a-terpineol. ${ }^{17}$ Tween 80 is a polyoxyethylene sorbitan fatty acid esters, with the chemical name of polyoxyethylene 20 sorbitan monooleate. The molecular formula is $\mathrm{C}_{64} \mathrm{H}_{124} \mathrm{O}_{26}$ in oil-like liquid form, bright yellow to light brown in colour, weak odour characteristics, bitter flavour, and warm. ${ }^{1}$ In the formula used as the mouth rinse, the Tween was used as a wetting agent, solvent, and suspender with a concentration of $0.01-12 \%$.

Sodium benzoate is used as a preservative due to its antibacterial and antifungal properties in acidic conditions. Saccharin is a white powder or crystal, odourless or has weak aromatic smell. It has a very sweet flavour In the form of an aqueous solution. ${ }^{18}$ In oral formulations, saccharin is used at the concentrations of $0.02-0.5 \%$. It is about 300-400 times as sweet as sucrose but has a bitter or metallic aftertaste, especially at high concentrations. ${ }^{1}$ Peppermint oil is one of the most popular and widely used essential oils because most of its main components are menthol and are used for typical odorants in oral preparations. The taste of peppermint oil is pleasant makes it an excellent stimulant for the stomach.

The organoleptic test results in Table 4 show that all solution formulas were homogeneous. The higher the concentration of essential oil, the higher the turbidity level due to the interaction between the components of essential oils and additives. Turbidity started to appear in formula IV (8\% essential oil).

The scents of formula I and II (concentrations of $1 \%$ and $2 \%$ essential oils) smelled of the minty aroma, but at the concentration of $4 \%$ (formula III), the distinctive fresh aroma of essential oils started to smell. All formulas tasted sweet and refreshing.
Organoleptic tests included characteristics of homogeneity, colour, aroma, and flavour needed to be done to ensure that the public will be able to accept the mouth rinse.

The $\mathrm{pH}$ value of a solution determines the type and ability of a bacterium to grow. Therefore, the $\mathrm{pH}$ for a mouth rinse solution should be in the $\mathrm{pH}$ range of the oral cavity, which is between 5.5 $7.9^{19}$ thus, when the preparation is consumed will not irritate the oral mucosa. The Herbal Medicines Quality Standards determine the $\mathrm{pH}$ value of herbal mouth rinse must be ranging from 5-7.20 The mouth rinse formula in the present study had a $\mathrm{pH}$ value that meets the quality standards. If the solution is too acidic, then the bacteria will proliferate, whereas a very alkaline solution will ease the growth of the fungus. Density and viscosity of the mouth rinse solution were also tested because these parameters can affect the solution thickness.

Additives in mouth rinse such as glycerin can affect the density and viscosity value. Antibacterial activity of the mouth rinse against a major etiological agent of human dental caries, S. mutans, to find the optimum concentration of essential oils used in the formula. The results showed that the formula with a concentration of $2 \%$ essential oils inhibited the growth of S. mutans with inhibition diameter of $6.15 \mathrm{~mm}$, and the highest inhibitory potential of $20 \%$ essential oils was $9.25 \mathrm{~mm}$. The recommended concentration of the mouth rinse was the formula III (4\% essential oil) due to a higher antibacterial activity.

Characteristics of the mouth rinse solution in this study were green in colour, homogeneous, clear, had a sweet flavour, smelled of distinctive fresh aroma of lime essential oil, had the $\mathrm{pH}$ value of 6.09 , density of 1.002 , and viscosity of 1.495 , with inhibitory potential on the growth of S. mutans in the diameter of $7.08 \mathrm{~mm}$. Based on previous research known that lime contains flavonoids which functioned as antioxidants. The concentration of flavonoids in lime peel is higher compared to other parts such as seeds and fruit. The high concentration of flavonoids makes the lime peel has potential antibacterial and antioxidant. ${ }^{21}$

The mechanism of essential oils in inhibiting and killing microorganisms is associated with their interactions with hydrophobic microorganisms, 
which causes the oil to be partitioned on the lipid bilayer cell membrane, which will affect the respiratory chain thus causes the leakage of bacterial cell contents. The weakness of the bacterial enzyme system can also be a potential mechanism of action. Various components of essential oils can increase the permeability of bacterial cells. ${ }^{22}$ Lime peel essential oils can inhibit the growth of $\mathrm{S}$. mutans bacteria by inhibiting the formation of pellicles and plaque, growth of bacterial colonies and also increasing salivary flow and decreasing salivary viscosity.

\section{CONCLUSION}

Mouth rinse formulation from essential oils of lime (Citrus aurantifolia) peel begins to show inhibition of the growth of $\mathrm{S}$. mutans bacteria at the concentration of $2 \%$ essential oils (formulation II), with inhibition against the growth of S. mutans is 7.08. The formula shows a minimum inhibitory concentration (MIC) value and a minimum bactericidal concentration (MBC) of $5.2 \mathrm{mg} / \mathrm{mL}$ $(0.52 \%)$ and $10.4 \mathrm{mg} / \mathrm{mL}$ (1.04), respectively.

\section{ACKNOWLEDGEMENT}

This study was funded by Bandung Polytechnic of Health and Universitas Padjadjaran, Indonesia.

\section{REFERENCES}

1. Patil RU, Dastoor PP, Unde MP. Comparative evaluation of antimicrobial effectiveness of probiotic milk and fluoride mouthrinse on salivary Streptococcus mutans counts and plaque scores in children - An in vivo experimental study. J Indian Soc Pedod Prev Dent 2019;37(4):378-82. DOI: 10.4103/ JISPPD. JISPPD_45_19

2. FDI World Dental Federation. The challenge of oral disease - a call for global action. The oral health atlas. $2^{\text {nd }}$ ed. Geneva: FDI World Dental Federation; 2015. p. 89.

3. Suwargiani AA, Pribadi IMS, Hidayat W, Wardani R, Jasrin TA, Zubaedah C. Caries experience, periodontal health, and oral treatment needs of pregnant women. $\mathrm{J}$ Ked Gi Univ Padjadjaran. 2018;30(1):20-5. DOI: 10.24198/jkg.v30i1.16282
4. Raynuary N, Suwargiani AA, Suryanti N. PUFA index of pregnant women who came to the Puter Community Health Centre, Bandung, Indonesia. J Ked Gi Univ Padjadjaran. 2017;29(2):99-105. DOI: $10.24198 / \mathrm{jkg}$. v29i2.18572

5. Gati D, Vieira AR. Elderly at greater risk for root caries: A look at the multifactorial risks with emphasis on genetics susceptibility. Int J Dent. 2011;2011:1-6. DOI: 10.1155/2011/647168

6. Rapp L, Maret D, Diemer F, Lacoste Ferré MH. Dental caries in geriatric dentistry: an update for clinicians. Int J Oral Dent Health. 2019; 5(1): 1-6. DOI: $10.23937 / 2469-5734 / 1510080$

7. National Institute of Health Research and Development (NIHRD). Indonesia basic health research (RISKESDAS) 2018. Jakarta: Ministry of Health Republic of Indonesia; 2018. p. 1823.

8. Salama MT, Alsughier ZA. Effect of green tea extract mouthwash on salivary streptococcus mutans counts in a group of preschool children: An in vivo study. Int J Clin Pediatr Dent. 2019;12(2):133-8. DOI: 10.5005/jpjournals-10005-1610

9. Budiani YA, Satari MH, Jasrin TA. Inhibitory potential of methanolic extract of pineapple, wuluh starfruit, and basil towards Streptococcus mutans ATCC 25175. J Ked Gi Univ Padjadjaran. 2017;29(2):124-30. DOI: 10.24198/jkg.v29i2.18575

10. Apriyanti EA, Satari MH, Laksono B. The antibacterial potential differences between the methanolic extract of ant-plant (Myrmecodia pendens Merr. \& Perry) tubers and $\mathrm{NaOCl}$ towards Streptococcus mutans (ATCC 25175). J Ked Gi Univ Padjadjaran. 2016;28(2):106-12. DOI: $10.24198 / \mathrm{jkg}$. v28i2.18704

11. Unita L, Singarimbun E. Antibacterial effect of the rosella flower extract towards the Streptococcus sp. colonies. J Ked Gi Univ Padjadjaran. 2018; 30(1): 64-9. DOI: $10.24198 /$ jkg.v30i1.18199

12. Aripin D. Julaeha E. Efektivitas minyak atsiri dari beberapa kulit jeruk sebagai antibakteri untuk penyakit mulut dan gigi [research report]. Bandung: Universitas Padjadjaran; 2015.

13. Raut JS, Karuppayil SM. A status review on 
the medicinal properties of essential oils. Industrial Crops Products. 2014; 62: 250-64. DOI: $10.1016 / j$.indcrop.2014.05.055

14. Chouhan S, Sharma K, Guleria S. Antimicrobial activity of some essential oils-present status and future perspectives. Medicines (Basel). 2017;4(3):1-21. DOI: 10.3390/ medicines 4030058

15. Preedy VR. Essential Oils in food preservation, flavor and safety. $1^{\text {st }}$ ed. Cambridge: Academic Press-Elsevier; 2016.

16. Dugo G, Mondello L. Citrus Oils: Composition, advanced analytical techniques, contaminants, and biological activity. Medicinal and aromatic plants - industrial profiles. Boca Raton: CRC Press; 2011.

17. Wahyudi T, Mulyawan AS, Kasipah C, Prayudie $\mathrm{U}$, Julaeha E. Preparation of citrus aurantifolia oil microcapsules for application in textile finishing. Arena Tekst. 2017;32(1):1-8.

18. Chattopadhyay S, RaychaudhuriU, Chakraborty R. Artificial sweeteners - a review. J Food Sci Technol. 2014;51(4):611-21. DOI: 10.1007/

\section{$\underline{\mathrm{s} 13197-011-0571-1}$}

19. Barman I, Umesh CPG. Effects of Habitual arecanut and tobacco chewing on resting salivary flow rate and $\mathrm{pH}$. Int $\mathrm{J}$ Oral Health Med Res. 2015;2(1):13-8.

20. Ministry of Health of the Republic of Indonesia. Farmakope Indonesia. $4^{\text {th }}$ ed. Jakarta: Ministry of Health of the Republic of Indonesia; 1995.

21. Elwan HAM, Dawood DH, El-Shafei SMAE, ElRahman AAEA, Abdel-Latif SA, Mohany M, et al. The potential role of citrus limon powder as a natural feed supplement to boost the productive performance, antioxidant status, and blood biochemistry of growing rabbits. Animals (Basel). 2019;9(7):426. DOI: 10.3390/ ani9070426

22. Oliveira SA, Zambrana JR, lorio FB, Pereira $C A$, Jorge $A O$. The antimicrobial effect of citrus limonum and citrus aurantium essential oils on multi-species biofilm. Braz Oral Res. 2014;28:22-7. DOI: 10.1590/s180683242013005000024 